\section{A Novel Right-Angled Ligand that Forms Polymeric Metal-Organic Frameworks with Nanometer-Sized Square Cavities}

Ken-Tsung Wong, ${ }^{*}, \dagger$ Yuan-Li Liao, ${ }^{\dagger}$ Ying-Chu Peng, ${ }^{\dagger}$ Chih-Chieh Wang, ${ }^{*},+$ Sue-Yi Lin, ${ }^{\ddagger}$ Cheng-Han Yang, ${ }^{\ddagger}$ Shih-Min Tseng, ${ }^{\ddagger}$ Gene-Hsiang Lee, ${ }^{\dagger}$ and Shie-Ming Peng ${ }^{\dagger}$

Department of Chemistry, National Taiwan University, Taipei 106, Taiwan, and Department of Chemistry, Soochow University, Taipei 111, Taiwan

Received June 2, 2004

\begin{abstract}
A new right angle-shaped ligand, 2,2'-bis(4-pyridyl)-9,9'-spirobifluorene (L), is designed and synthesized. Treatment of $\mathbf{L}$ with silver(I) ions leads to linear polymeric metal-organic frameworks, $\left[\mathrm{Ag}(\mathbf{L})_{2}\right]^{+}(\mathbf{1})$, that feature square subunits. Single-crystal X-ray analysis reveals that $\left[\mathrm{Ag}(\mathbf{L})_{2}\right]^{+}$has a one-dimensional double-stranded polymeric chain comprising square grids with cavity dimensions of ca. $8 \AA \times 8 \AA$. By $\pi-\pi$ stacking of adjacent double-stranded chains, the structure is extended into a two-dimensional (2D) layer framework with a unique quasiaperture (dimensions of ca. $14 \AA \times 8 \AA$ ). Each $2 \mathrm{D}$ layer is inclined and mutually interpenetrated, which gives rise to the three-dimensional interlocked network structure. Compound $\mathbf{1} \cdot\left(\mathrm{BF}_{4}\right)\left(\mathrm{CH}_{3} \mathrm{OH}\right)$ crystallizes in the monoclinic system, space group $C 2 / c$, with chemical formula $\mathrm{C}_{71} \mathrm{H}_{49} \mathrm{~N}_{4} \mathrm{OBF}_{4} \mathrm{Ag}, a=25.709(1) \AA, b=14.4164(6) \AA, c=15.6865$ (7) $\AA, \beta=109.220(2)^{\circ}$, and $Z=4$.
\end{abstract}

\section{Introduction}

The self-assembly of supramolecules with well-defined architectures from metal ions and organic ligands continues to attract much attention because of their potential applications in a variety of fields. The architectures and functions of such self-assembled systems rely on the design of the molecular components (ligands) and the choice of the metal ions. The advanced state of modern synthetic methodology makes feasible the synthesis of designed organic ligands with sophisticated structures and predetermined shapes; when combined with the vast range of coordination geometries that metal ions possess, a wide range of novel structures can be developed depending on the information programmed in the constituent parts. A diverse array of twodimensional (2D) and three-dimensional (3D) supramolecular architectures, such as squares, helicates, racks, ladders, grids, cages, bowls, tubes, capsules, polygons, and polyhedrons, have been prepared as stable complexes. ${ }^{1}$ The construction of these $2 \mathrm{D}$ and $3 \mathrm{D}$ metalosupramolecules takes advantage of the fact that the metal ions act as both the "cement" that holds the ligands in place and the centers that direct the orientation of the ligands outward. To construct supramolecules with right-angled $\left(90^{\circ}\right)$ arrangements of their ligands, tetrahedrally coordinated metal ions are often used as the intersect centers, e.g., for the preparation of a [ $2 \times$ 2] grid. ${ }^{2}$ A similar strategy has been applied to the successful synthesis of squarelike supramolecules, ${ }^{3}$ in this case by positioning square-planar-coordinated metal centers at the corners. Predesigned organic ligands with two coordination sites arranged perpendicular to one another are relatively less explored; 5,10-bis(4-pyridyl)-

\footnotetext{
* To whom correspondence should be addressed. Present address:
} Department of Chemistry, National Taiwan University, Taipei 106, Taiwan. E-mail: kenwong@ccms.ntu.edu.tw.

$\dagger$ National Taiwan University.

$\ddagger$ Soochow University. porphyrin $^{4}$ is probably the most-studied ligand for preparing molecular squares using different metals. An elegant self-assembled molecular square with a cis-1,2bis(4-pyridyl)cyclobutane derivative as the right-angled ligand has been characterized recently. ${ }^{5}$ The $9,9^{\prime}$-spirobifluorene constitutes two biphenyl groups linked almost perpendicularly through a carbon center, and as such, we anticipated that its rigid skeleton would present the potential to develop new right angle-shaped ligands as components for supermolecules. The challenge is the selective introduction of two groups at the C2 and C2' positions of $9,9^{\prime}$-spirobifluorene that are capable of coordinating to metal ions. In this contribution, we report the synthesis and characterization of a novel ligand with a $9,9^{\prime}$-spirobifluorene core that presents its two coordination sites in a right-angled geometry and, additionally, the formation of a supramolecular complex between these ligands and silver(I) ions.

\section{Experimental Procedures}

General Experiments. All reactions were performed under argon and were magnetically stirred. Solvents were distilled from the appropriate dying agent prior to use: tetrahydrofuran (THF) and $\mathrm{Et}_{2} \mathrm{O}$ from sodium and benzophenone, benzene and toluene from sodium, and $\mathrm{CH}_{2} \mathrm{Cl}_{2}$ from $\mathrm{CaH}_{2}$. Commercially available reagents were used without further purification unless otherwise stated. All reactions were monitored by thinlayer chromatography with Macherey-Nagel precoated aluminum foil sheets $\left(0.20 \mathrm{~mm}\right.$ with fluorescent indicator $\left.\mathrm{UV}_{254}\right)$. The compounds were visualized with UV light at 254 and 365 $\mathrm{nm}$. The melting points were measured on a Fargo MP-1D and are uncorrected. Infrared (IR) spectra were recorded within $\mathrm{KBr}$ on a Nicolet FT-IR spectrometer. ${ }^{1} \mathrm{H}$ NMR and ${ }^{13} \mathrm{C}$ NMR in $\mathrm{CDCl}_{3}$ were recorded using a Bruker (Avance 4000) or Varian (Unity Plus 400) spectrometer at 400 and $100 \mathrm{MHz}$, respectively. Low- and high-resolution mass spectra were recorded using a JEOL SX-102A spectrometer in fast atom bombardment (FAB) mode. Microanalyses were carried out on a Perkin-Elmer CHN-2400 or a Heraeus Vario EL-III analyzer.

Synthesis of 2,2'-Diamino-9,9'-spirobifluorene (2). ${ }^{6} 2,2^{\prime}$ Dinitro-9,9'-spirobifluorene (1) ${ }^{6,7}(20.9 \mathrm{~g} ; 50 \mathrm{mmol})$ and $\mathrm{Pd} / \mathrm{C}$ 
(0.54 g; $5 \mathrm{mmol})$ were mixed in ethanol $(150 \mathrm{~mL})$ and EtOAc (600 mL). The reaction mixture was stirred for $48 \mathrm{~h}$ under $\mathrm{H}_{2}$, filtered, and concentrated by evaporation under reduced pressure. The residue was dissolved in EtOAc and washed with hexane to afford the title compound as a white solid (17.3 g; 98\%). ${ }^{1} \mathrm{H} \mathrm{NMR}\left(\mathrm{CDCl}_{3}, 400 \mathrm{MHz}\right): 7.68(\mathrm{~d}, J=7.6 \mathrm{~Hz}, 2 \mathrm{H})$, $7.60(\mathrm{~d}, J=8.1 \mathrm{~Hz}, 2 \mathrm{H}), 7.30(\mathrm{t}, J=7.5 \mathrm{~Hz}, 2 \mathrm{H}), 7.00(\mathrm{t}, J=$ $7.5 \mathrm{~Hz}, 2 \mathrm{H}), 6.71(\mathrm{~d}, J=7.5 \mathrm{~Hz}, 2 \mathrm{H}), 6.65(\mathrm{~d}, J=8.1 \mathrm{~Hz}, 2 \mathrm{H})$, $6.06(\mathrm{~s}, 2 \mathrm{H}), 3.42(\mathrm{~s}, 4 \mathrm{H}) .{ }^{13} \mathrm{C} \mathrm{NMR}\left(\mathrm{CDCl}_{3}, 100 \mathrm{MHz}\right): 151.1$, 148.3, 146.4, 142.1, 136.2, 127.4, 127.0, 126.0, 123.9, 120.7, $118.5,114.6,110.7,65.5$.

Synthesis of $2,2^{\prime}$-Bis(3,3-diethyltriazenyl)-9,9' -spirobifluorene (3). To a flask charged with 2,2'-diamino-9,9' spirobifluorene (2) (1.08 g; $2 \mathrm{mmol})$ were added concentrated $\mathrm{HCl}(5.2 \mathrm{~mL})$ and $\mathrm{H}_{2} \mathrm{O}(40 \mathrm{~mL})$. To this mixture, cooled with an ice bath and stirred, a solution of sodium nitrite $(1.81 \mathrm{~g}$; $26.1 \mathrm{mmol})$ in $\mathrm{H}_{2} \mathrm{O}(16 \mathrm{~mL})$ was added dropwisely. The reaction mixture was allowed to stir at $0{ }^{\circ} \mathrm{C}$ for $30 \mathrm{~min}$ until a homogeneous solution was obtained, transferred to a solution containing $\mathrm{K}_{2} \mathrm{CO}_{3}$ (14.40 g; $1.52 \mathrm{mmol}$ ), Et ${ }_{2} \mathrm{NH}$ (2.4 mL, 22.88 mmol), acetonitrile $(180 \mathrm{~mL})$, and $\mathrm{H}_{2} \mathrm{O}(35 \mathrm{~mL})$, and cooled in an ice bath. The reaction mixture was then allowed to stir for $30 \mathrm{~min}$ at room temperature. More $\mathrm{H}_{2} \mathrm{O}(500 \mathrm{~mL})$ was added, and the product was collected as a brown powder by filtration (4.32 g; 84\%); mp $197-198^{\circ} \mathrm{C}$. IR (KBr): $2981(\mathrm{w}), 1451(\mathrm{~m})$, $1345(\mathrm{~m}), 1116(\mathrm{~m}), 761(\mathrm{~m}) .{ }^{1} \mathrm{H}$ NMR $\left(\mathrm{CDCl}_{3}, 400 \mathrm{MHz}\right): 7.78$ $(\mathrm{d}, J=8.0 \mathrm{~Hz}, 4 \mathrm{H}), 7.44(\mathrm{~d}, J=8.1 \mathrm{~Hz}, 2 \mathrm{H}), 7.33(\mathrm{t}, J=7.5$ $\mathrm{Hz}, 2 \mathrm{H}), 7.04(\mathrm{t}, J=7.5 \mathrm{~Hz}, 2 \mathrm{H}), 6.84(\mathrm{~s}, 2 \mathrm{H}), 6.72(\mathrm{~d}, J=8.0$ $\mathrm{Hz}, 2 \mathrm{H}$ ), 3.65 (q, $J=7.2 \mathrm{~Hz}, 8 \mathrm{H}), 1.16$ (t, $J=8.0 \mathrm{~Hz}, 12 \mathrm{H}$ ). ${ }^{13} \mathrm{C}$ NMR $\left(\mathrm{CDCl}_{3}, 100 \mathrm{MHz}\right): \delta 151.2,149.6,149.3,141.8$, $138.9,127.4,127.0,124.0,120.0,119.9,119.4,116.6,65.9 . \mathrm{MS}$ $\left(\mathrm{m} / z, \mathrm{FAB}^{+}\right): 515(85), 514(75), 414(50), 314$ (100). HRMS $\left(\mathrm{M}^{+}, \mathrm{FAB}^{+}\right)$calcd $\mathrm{C}_{33} \mathrm{H}_{34} \mathrm{~N}_{6}, 514.2845$; found, 514.2850.

Synthesis of 2,2'-Diiodo-9,9' -spirobifluorene (4). A sealed tube was charged with 2,2'-bis(3,3-diethyltriazenyl)-9, $9^{\prime}$-spirobifluorene (3) (3.46 g; $10 \mathrm{mmol})$ and methyl iodide $(10 \mathrm{~mL})$. The tube was degassed with nitrogen and heated to $110{ }^{\circ} \mathrm{C}$ in an oil bath for $5 \mathrm{~h}$. The solvent was removed, and the residue was purified by column chromatography using hexane as an eluent to afford the product as a white solid (1.09 g; 96\%); mp 197-198 ${ }^{\circ} \mathrm{C}$. IR (KBr): $3047(\mathrm{w}), 1602(\mathrm{w}), 1451(\mathrm{~s}), 754(\mathrm{~s})$. ${ }^{1} \mathrm{H} \mathrm{NMR}\left(\mathrm{CDCl}_{3}, 400 \mathrm{MHz}\right): 7.82(\mathrm{~d}, J=7.0 \mathrm{~Hz}, 2 \mathrm{H}), 7.71(\mathrm{~d}$, $J=6.4 \mathrm{~Hz}, 2 \mathrm{H}), 7.59(\mathrm{~d}, J=7.9 \mathrm{~Hz}, 2 \mathrm{H}), 7.39(\mathrm{t}, J=7.6 \mathrm{~Hz}$, $2 \mathrm{H}), 7.17(\mathrm{t}, J=7.0 \mathrm{~Hz}, 2 \mathrm{H}), 7.03(\mathrm{~s}, 2 \mathrm{H}), 6.71(\mathrm{t}, J=7.7 \mathrm{~Hz}$, $2 \mathrm{H}) .{ }^{13} \mathrm{C} \mathrm{NMR}\left(\mathrm{CDCl}_{3}, 100 \mathrm{MHz}\right): 150.0,147.5,141.3,140.7$, 137.1, 133.1, 128.6, 128.2, 124.0, 121.8, 120.2, 93.0, 65.4. MS $\left(\mathrm{m} / z, \mathrm{FAB}^{+}\right): 568(10), 460(15), 307(100), 289$ (45). HRMS $\left(\mathrm{M}^{+}, \mathrm{FAB}^{+}\right.$) calcd $\mathrm{C}_{25} \mathrm{H}_{14} \mathrm{I}_{2}, 567.9185$; found, 567.9182. Anal. calcd: C, 52.85; H, 2.48. Found: C, 52.55; H, 2.60.

Synthesis of 2,2 '-Bis $(4,4,5,5$-tetramethyl-1,3,2-dioxaborolan-2-yl)-9,9' -spirobifluorene (5). A solution of $t$-BuLi $(1.8 \mathrm{~mL} ; 1.7 \mathrm{M}$ in hexane; $3 \mathrm{mmol}$ ) was added dropwise to a stirred solution of $2,2^{\prime}$-diiodo-9,9'-spirobifluorene (4) $(0.29 \mathrm{~g}$; $0.5 \mathrm{mmol})$ in THF $(15 \mathrm{~mL})$ at $-78^{\circ} \mathrm{C}$. After the solution was stirred for $1 \mathrm{~h}, 2$-isopropoxy-4,4,5,5-tetramethyl[1,3,2]dioxaborolane $(0.4 \mathrm{~mL} ; 2 \mathrm{mmol})$ was added rapidly. The stirring mixture was kept for $30 \mathrm{~min}$ at $-78^{\circ} \mathrm{C}$ and then allowed to warm to room temperature. The solvent was removed by evaporation under reduced pressure, and the residue was extracted with $\mathrm{CH}_{2} \mathrm{Cl}_{2}$. The organic layer was washed with brine and dried over anhydrous $\mathrm{MgSO}_{4}$. The solvent was removed, while the residue was recrystallized from pentane to give the product as a white solid $(0.47 \mathrm{~g} ; 60 \%)$; $\mathrm{mp} 204-$ $205^{\circ} \mathrm{C}$. IR (KBr): $v 2981(\mathrm{~s}), 1608(\mathrm{~s}), 1359(\mathrm{~s}), 1148$ (s), 735 (s). ${ }^{1} \mathrm{H} \mathrm{NMR}\left(\mathrm{CDCl}_{3}, 400 \mathrm{MHz}\right): \delta 7.87-7.86(\mathrm{~m}, 6 \mathrm{H}), 7.35(\mathrm{t}$, $J=7.5 \mathrm{~Hz}, 2 \mathrm{H}), 7.17(\mathrm{~s}, 2 \mathrm{H}), 7.09(\mathrm{t}, J=7.4 \mathrm{~Hz}, 2 \mathrm{H}), 6.66(\mathrm{~d}$, $J=7.6 \mathrm{~Hz}, 2 \mathrm{H}), 1.26(\mathrm{~s}, 24 \mathrm{H}) .{ }^{13} \mathrm{C} \mathrm{NMR}\left(\mathrm{CDCl}_{3}, 100 \mathrm{MHz}\right): \delta$ $149.5,147.5,145.0,141.5,134.7,130.4,128.3,127.6,124.1$, $120.4,119.3,83.7,65.9,24.8 . \mathrm{MS}\left(\mathrm{m} / z, \mathrm{FAB}^{+}\right): 568(100), 567$ (40), 307 (10), 289 (10). HRMS $\left(\mathrm{M}^{+}, \mathrm{FAB}^{+}\right.$) calcd $\mathrm{C}_{37} \mathrm{H}_{38} \mathrm{~B}_{2} \mathrm{O}_{4}$, 568.2956; found, 568.2960.

Synthesis of 2,2'-Bis(4-pyridyl)-9,9'-spirobifluorene (L). 2,2'-Bis(4,4,5,5-tetramethyl-1,3,2-dioxaborolan-2-yl)-9,9'-spirobifluorene (5) (1.66 g; $2.9 \mathrm{mmol}$ ), 4-bromopyridine hydrochloride (1.7 g; $8.8 \mathrm{mmol}), \mathrm{Pd}\left(\mathrm{PPh}_{3}\right)_{4}(0.1 \mathrm{~g} ; 0.087 \mathrm{mmol}), 2 \mathrm{M}$
$\mathrm{Na}_{2} \mathrm{CO}_{3}(\mathrm{aq})(100 \mathrm{~mL})$, and $\mathrm{P}^{t} \mathrm{Bu}_{3}(3.5 \mathrm{~mL} ; 0.05 \mathrm{M}$ in toluene; $0.175 \mathrm{mmol})$ were dissolved in 1,4-dioxane $(200 \mathrm{~mL})$. The resulting reaction mixture was refluxed under argon for $72 \mathrm{~h}$, cooled, and extracted with $\mathrm{CH}_{2} \mathrm{Cl}_{2}$. The organic extract was dried with anhydrous $\mathrm{MgSO}_{4}$, concentrated, and purified by column chromatography (EtOAc) to afford the title compound as a white solid (1.96 g; 82\%); $\mathrm{mp} 268-269^{\circ} \mathrm{C}$. IR (KBr): 3034 (m), $1595(\mathrm{~s}), 1457(\mathrm{~s}), 820(\mathrm{~s}) \mathrm{cm}^{-1} .{ }^{1} \mathrm{H} \mathrm{NMR}\left(\mathrm{CDCl}_{3}, 400\right.$ MHz): $8.53-8.51(\mathrm{~m}, 4 \mathrm{H}), 7.97(\mathrm{~d}, J=8.0 \mathrm{~Hz}, 2 \mathrm{H}), 7.91(\mathrm{~d}, J$ $=8.0 \mathrm{~Hz}, 2 \mathrm{H}), 7.69(\mathrm{dd}, J=8.0 \mathrm{~Hz}, 2 \mathrm{H}), 7.42(\mathrm{t}, J=8.0 \mathrm{~Hz}$, $2 \mathrm{H}), 7.34-7.26(\mathrm{~m}, 4 \mathrm{H}), 7.16(\mathrm{t}, J=8.0 \mathrm{~Hz}, 2 \mathrm{H}), 7.01(\mathrm{~d}, J=$ $1.0 \mathrm{~Hz}, 2 \mathrm{H}), 6.7(\mathrm{~d}, J=8.0 \mathrm{~Hz}, 2 \mathrm{H}) .{ }^{13} \mathrm{C} \mathrm{NMR}\left(\mathrm{CDCl}_{3}, 100\right.$ MHz): 150.1, 149.4, 148.8, 147.8, 142.9, 140.9, 137.8, 128.5, 128.1, 127.0, 124.1, 122.5, 121.4, 120.8, 120.5, 66.0. MS (m/z, $\left.\mathrm{FAB}^{+}\right): 471.2(100), 470.2(25), 339.1(15), 307.1(25), 279.1$ (15). HRMS ( $\mathrm{M}+\mathrm{H}^{+}, \mathrm{FAB}^{+}$) calcd $\mathrm{C}_{35} \mathrm{H}_{23} \mathrm{~N}_{2}, 471.1861$; found, 471.1865 .

Synthesis of $\left[\mathrm{Ag}(\mathrm{L})_{2}\right] \cdot\left(\mathrm{BF}_{4}\right) \cdot \mathbf{2}\left(\mathrm{H}_{2} \mathrm{O}\right)(6)$. A solution of $\mathrm{AgBF}_{4}$ (0.01 mmol) and 2,2'-bis(4-pyridinyl)-9,9'-spirobifluorene $(\mathbf{L})(0.02 \mathrm{mmol})$ in $\mathrm{CH}_{3} \mathrm{CN}(40 \mathrm{~mL})$ was stirred for $2 \mathrm{~h}$ at room temperature. The resulting colorless solution was filtered and concentrated to $5 \mathrm{~mL}$. A white powder of compound 6 was obtained in $47 \%$ yield after slow diffusion of diethyl ether into the filtrate over a 2 week period.

Crystallographic Data Collection and Refinement. The chosen crystals of $\mathbf{L}$ and compound $\mathbf{6}$ were mounted on a glass fiber. Data collections were carried out on a Siemens SMART diffractomer with a CCD detector with Mo radiation $(\lambda=0.71073 \AA)$ at room temperature. A preliminary orientation matrix and unit cell parameters were determined from three runs of 15 frames each; each frame corresponds to a $0.3^{\circ}$ scan in $10 \mathrm{~s}$, followed by spot integration and least-squares refinement. For each structure, data were measured using $\omega$ scans of $0.3^{\circ}$ per frame for $20 \mathrm{~s}$ until a complete hemisphere had been collected. Cell parameters were retrieved using SMART $^{8}$ software and refined with SAINT $^{9}$ on all observed reflections. Data reduction was performed with the SAINT ${ }^{9}$ software and corrected for Lorentz and polarization effects. Absorption corrections were applied with the program SADABS. ${ }^{10}$ Direct phase determination and subsequent difference Fourier map synthesis yielded the positions of all nonhydrogen atoms, which were subjected to anisotropic refinements. All hydrogen atoms were fixed at calculated positions and refined using a riding mode. The final full-matrix, least-squares refinement on $F^{2}$ was applied for all observed reflections $[I>$ $2 \sigma(I)]$. All calculations were performed by using the SHELXTLPC V 5.03 software package. ${ }^{11}$ Crystallographic data and experimental details of refinements for structural analyses are given in Table 1 . The space-filling representation of ligand $\mathbf{L}$ and complex 6 are performed by Diamond V 2.1d.

Crystallographic data (excluding structure factors) of $\mathbf{L}$ and compound $\mathbf{6}$ for the structures reported in this paper have been deposited with the Cambridge Crystallographic Data Centre as supplementary publication nos. ccdc231486 and ccdc231487. Copies of the data can be obtained free of charge on application to CCDC.

\section{Results and Discussion}

Syntheses of 2,2'-Bis(4-pyridyl)-9,9'-spirobifluorene $(L)$ and Compound 6 . To maintain linearity along the long axes of the biphenyl units, we chose to introduce 4-pyridyl units as the coordination sites; Scheme 1 depicts the synthetic procedure of 2,2'-bis(4pyridyl)-9,9'-spirobifluorene ( $\mathbf{L}$ ).

The synthesis of ligand $\mathbf{L}$ began with the regioselective functionalization of the $\mathrm{C} 2$ and $\mathrm{C} 2$ ' positions of 9,9'spirobifluorene. It is possible, starting from 9,9'spirobifluorene, to perform regioselective nitration under carefully controlled conditions ${ }^{6,7}$ because the strong electron-withdrawing character of the nitro groups makes double nitration of a single biphenyl unit more 
Table 1. Crystal Data and Refinement Details of $L \cdot T H F$ and $\left[\mathrm{Ag}(\mathrm{L})_{2}\right] \cdot \mathrm{BF}_{4} \cdot \mathrm{CH}_{3} \mathrm{OH}(6)$

\begin{tabular}{|c|c|c|}
\hline & $\mathbf{L} \cdot \mathrm{THF}$ & 6 \\
\hline empirical formula & $\mathrm{C}_{39} \mathrm{H}_{30} \mathrm{~N}_{2} \mathrm{O}$ & $\mathrm{C}_{71} \mathrm{H}_{49} \mathrm{AgBF}_{4} \mathrm{~N}_{4} \mathrm{O}$ \\
\hline formula mass $\left(\mathrm{g} \mathrm{mol}^{-1}\right)$ & 542.65 & 1168.82 \\
\hline crystal system & monoclinic & monoclinic \\
\hline space group & $P 2_{1} / c$ & $C 2 / c$ \\
\hline$a(\AA)$ & $18.3445(11)$ & $25.709(1)$ \\
\hline$b(\AA)$ & $9.5239(6)$ & $14.4164(6)$ \\
\hline$c(\AA)$ & $17.1652(11)$ & $15.6865(7)$ \\
\hline$\alpha(\mathrm{deg})$ & 90.0 & 90.0 \\
\hline$\beta$ (deg) & $94.466(1)$ & $109.220(2)$ \\
\hline$\gamma(\operatorname{deg})$ & 90.0 & 90.0 \\
\hline$V\left(\AA^{3}\right)$ & 2989.8(3) & $5489.9(4)$ \\
\hline$Z$ & 4 & 4 \\
\hline$D_{\text {calcd }}\left(\mathrm{g} \mathrm{cm}^{-3}\right)$ & 1.206 & 1.414 \\
\hline$\mu\left(\mathrm{mm}^{-1}\right)$ & 0.072 & 0.432 \\
\hline$\theta$ range (deg) & $1.11-25.0$ & $1.64-25.0$ \\
\hline total no. of data collected & 18223 & 17879 \\
\hline no. of unique data & 5270 & 4842 \\
\hline no. of obsd data $[I>2 \sigma(I)]$ & 2551 & 2725 \\
\hline$R_{\text {int }}$ & 0.0564 & 0.0649 \\
\hline refine params & 380 & 425 \\
\hline$R_{1}, w R_{2}{ }^{a}[I>2 \sigma(I)]$ & $0.0974,0.3001$ & $0.0677,0.1774$ \\
\hline$R_{1}, w R_{2}{ }^{a}$ (all data) & $0.1704,0.3272$ & $0.1236,0.2136$ \\
\hline $\mathrm{GOF}^{b}$ & 1.231 & 1.022 \\
\hline
\end{tabular}

Scheme $1^{a}$

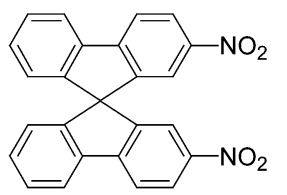

1

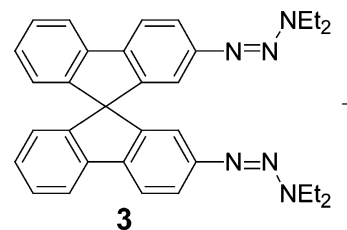

3

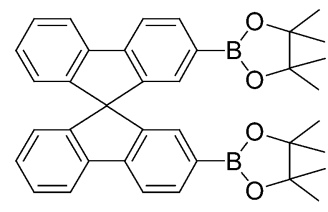

5

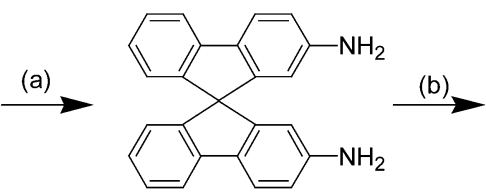

2
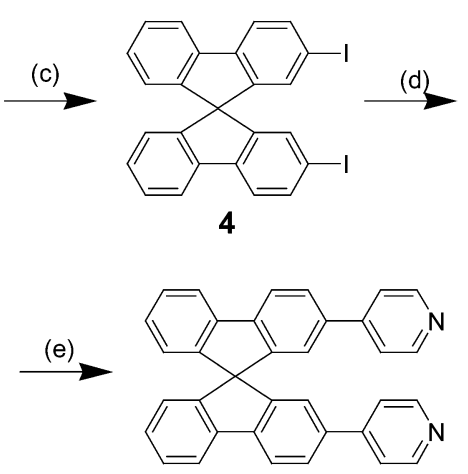

$\mathbf{L}$

${ }^{a}$ Reagents and conditions: (a) $\mathrm{H}_{2}, \mathrm{Pd} / \mathrm{C}$. (b) $\mathrm{NaNO}_{2}, \mathrm{HCl}$, $\mathrm{CH}_{3} \mathrm{CN}, 0{ }^{\circ} \mathrm{C}$, then $\mathrm{Et}_{2} \mathrm{NH}$ to room temperature. (c) $\mathrm{CH}_{3} \mathrm{I}$, sealed tube, $100{ }^{\circ} \mathrm{C}$. (d) (i) $t$-BuLi, THF, $-78{ }^{\circ} \mathrm{C}$; (ii) 2 -isopropoxy-4,4,5,5tetramethyl[1,3,2] dioxaborolane, $-78^{\circ} \mathrm{C}$ to room temperature. (e) 4-Bromopyridine hydrochloride, $\mathrm{Pd}\left(\mathrm{PPh}_{3}\right)_{4}, 2.0 \mathrm{M} \mathrm{Na}_{2} \mathrm{CO}_{3}$, toluene.

difficult to achieve; thus, we isolated $2,2^{\prime}$-dinitro-9,9'spirobifluorene (1) in high yield (85\%). The nitro groups of $\mathbf{1}$ were then readily reduced by Pd-catalyzed hydrogenation to afford the diamino compound $\mathbf{2}$ with an isolated yield of $98 \%$. Rather than following a modified Sandmeyer reaction approach,,$^{12}$ we converted the diamine $\mathbf{2}$ into the diethyltriazenyl derivative $\mathbf{3}$ using Moore's method..$^{13}$ The subsequent reaction of $\mathbf{3}$ with $\mathrm{CH}_{3} \mathrm{I}$ in a sealed tube at $100{ }^{\circ} \mathrm{C}$ afforded $2,2^{\prime}$-diiodo$9,9^{\prime}$-spirobifluorene (4) in $96 \%$ yield. ${ }^{14}$ Treatment of the diiodospirofluorene 4 with an excess amount of $t$-BuLi at $-78{ }^{\circ} \mathrm{C}$, followed by quenching of the dilithiated

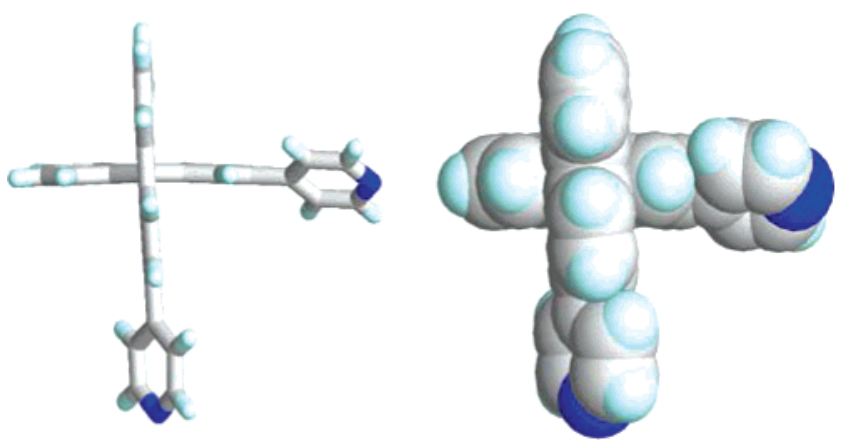

Figure 1. Solid state structure of the right angle-shaped ligand $\mathbf{L}$ with space-filling representation. Only the $R$ configuration is presented; cocrystallized THF has been omitted for clarity.

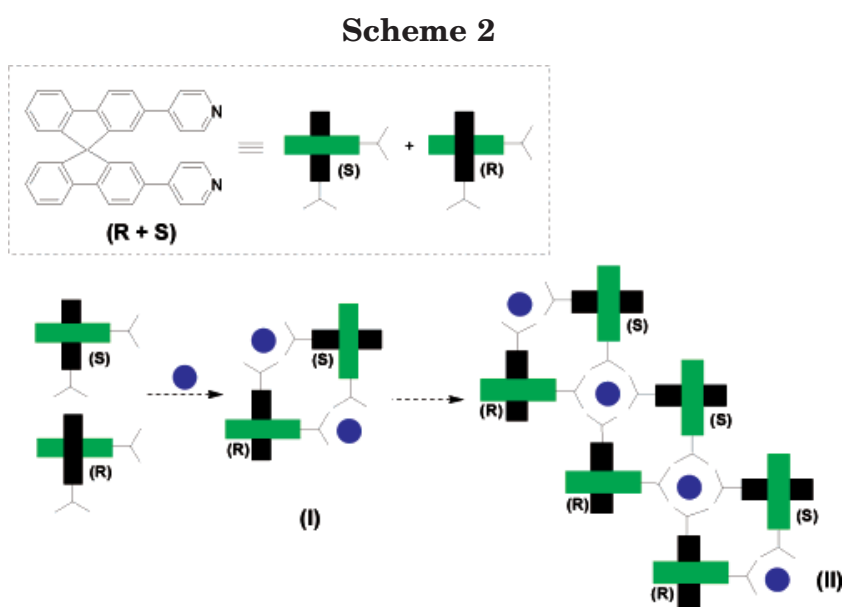

intermediate with 2-isopropoxy-4,4,5,5-tetramethyl$[1,3,2]$ dioxaborolane, gave the desired diboronic ester 5 in $60 \%$ yield. The Suzuki coupling reaction of the diboronic ester 5 with 4-bromopyridine in the presence of a catalytic amount of $\mathrm{Pd}\left(\mathrm{PPh}_{3}\right)_{4}$ furnished the target ligand $\mathbf{L}$ in an isolated yield of $82 \%$.

We obtained satisfactory spectroscopic data to characterize this novel right-angled ligand. Single crystals of $\mathbf{L}$ that we obtained from a THF/hexanes solution were subjected to X-ray crystallographic analysis. Figure 1 presents stick and space-filling models of the solid state structure of ligand $\mathbf{L}$. The pyridyl rings are slightly twisted from the planes of the fluorene units with an average dihedral angle of $32.4^{\circ}$. The dihedral angle between the two spiro-linked aryl branches is observed to be $87.9^{\circ}$. Clearly, the solid state structure of $\mathbf{L}$ confirms our expectation for an orthogonal configuration of the two coordination sites. Because the ligand is chiral, we isolated $\mathbf{L}$ as a racemic mixture. Scheme 2 depicts idealized architectures expected when $\mathbf{L}$ is combined with suitable metal ions. One can imagine forming a small square (I) that consists of two ligands with opposite configurations positioned diagonally and linked by two metal ions. In this case, both the spiro carbon atom and the metal ion centers act as corners of the square. It is possible that the metal ion corners can complex further with extra ligands $\mathbf{L}$, which would result in the formation of a linear polymeric twostranded metal-organic framework (MOF), II, comprising an infinite array of linked square cavities along the progressing direction. 


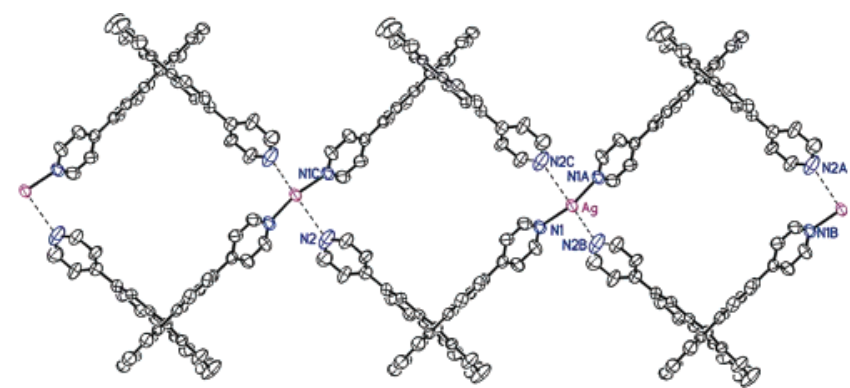

Figure 2. ORTEP drawing of compound 6 at the $50 \%$ probability level. The $\mathrm{BF}_{4}^{-}$and $\mathrm{CH}_{3} \mathrm{OH}$ molecules have been omitted for clarity.

Table 2. Selected Bond Lengths $(\AA)$ and Angles $\left(^{\circ}\right)$ for the Silver(I) Coordination Spheres in Compound $6^{a}$

\begin{tabular}{lrlr}
\hline $\mathrm{Ag}-\mathrm{Ag} \# 1$ & $0.661(3)$ & $\mathrm{Ag}-\mathrm{N}(1)$ & $2.129(6)$ \\
$\mathrm{Ag}-\mathrm{N}(1) \# 1$ & $2.230(6)$ & $\mathrm{Ag}-\mathrm{N}(2) \# 2$ & $2.726(6$ \\
$\mathrm{Ag}-\mathrm{N}(2) \# 3$ & $3.362(6)$ & & \\
$\mathrm{N}(1)-\mathrm{Ag}-\mathrm{N}(1) \# 1$ & $162.75(9)$ & $\mathrm{N}(1)-\mathrm{Ag}-\mathrm{N}(2) \# 2$ & $97.98(9)$ \\
$\mathrm{N}(1)-\mathrm{Ag}-\mathrm{N}(2) \# 3$ & $80.15(9)$ & $\mathrm{N}(1) \# 1-\mathrm{Ag}-\mathrm{N}(2) \# 2$ & $98.65(9)$ \\
$\mathrm{N}(1) \# 1-\mathrm{Ag}-\mathrm{N}(2) \# 3$ & $83.01(9)$ & $\mathrm{N}(2) \# 2-\mathrm{Ag}-\mathrm{N}(2) \# 3$ & $176.54(9)$
\end{tabular}

a Symmetry transformations used to generate equivalent atoms. No. 1: $1-x, 1-y, 1-z$. No. $2: 0.5+x,-0.5+y, z$. No. $3: 0.5$ $-x, 1.5-y, 1-z$.

To test whether such a structure does indeed form, we stirred a solution of $\mathrm{AgBF}_{4}(0.01 \mathrm{mmol})$ and $2,2^{\prime}-$ bis(4-pyridinyl)-9,9'-spirobifluorene in $\mathrm{CH}_{3} \mathrm{CN}(40 \mathrm{~mL})$ for $2 \mathrm{~h}$ at room temperature. Compound 6 was obtained after slow diffusion of diethyl ether into the filtrate. Single crystals of compound 6 suitable for X-ray crystallographic analysis were also obtained from this solution.

Description of Structure. $\left[\mathrm{Ag}(\mathrm{L})_{2}\right] \mathrm{BF}_{4} \cdot \mathrm{CH}_{3} \mathrm{OH}$ (6). Figure 2 presents the ORTEP drawing of the silver(I)-centered compound 6 . The selected bond lengths and bond angles around the silver(I) ion are listed in Table 2. The silver(I) ion is located disorderedly at two equivalent sites with a $\mathrm{Ag}-\mathrm{Ag}$ distance of $0.661 \AA$ and is coordinated selectively by two nitrogen atoms of two individual $\mathbf{L}$ ligands in trans positions with $\mathrm{N}(1)-\mathrm{Ag}-$ $\mathrm{N}(1)$ bond angles of $162.75(9)^{\circ}$, forming a $\left[\mathrm{AgL}_{2}\right]^{+}$ fragment with average $\mathrm{Ag}-\mathrm{N}(1)$ distances of 2.178(1) $\AA$ [2.129(6) and 2.230(6) $\AA$ ]. The strong steric interactions between the bulky $\mathbf{L}$ ligands prevent the formation of the expected cis-coordinated structure (MOF I, Scheme 2 ) as a primary building unit. It is worthy to note that the absolute configurations of the two $\mathbf{L}$ ligands in the $\left[\mathrm{AgL} \mathbf{L}_{2}\right]^{+}$fragments are opposite. The two coordinated pyridyl rings of $\mathbf{L}$ in $\mathbf{6}$ are also slightly twisted from the planes of their fluorene units with dihedral angles of $34.72(1)^{\circ}$. The dihedral angles between the two spirolinked aryl branches average $88^{\circ}$, which is practically identical to that of the free ligands in the crystal form (see above). Neighboring $\left[\mathrm{Ag} \mathbf{L}_{2}\right]^{+}$fragments are then self-assembled through weak Ag $\cdots \mathrm{N}$ interactions between the remaining two coordination sites of their Ag(I) ions and the remaining uncoordinated nitrogen atoms of ligands $\mathbf{L}$ with average $\mathrm{Ag}-\mathrm{N}(2)$ distances of $3.044(7) \AA[2.726(6)$ and 3.362(6) $\AA]$. As a result, onedimensional double-stranded chains, analogous to the MOF II depicted in Scheme 2, are formed along the $(1 \overline{1} 0)$ and (110) directions. The slightly twisted square cavities serve as the basic building units (Figure 2) with all of the $R$-configured ligands located at one side and the $S$-configured ones at the other side. A metallacycle

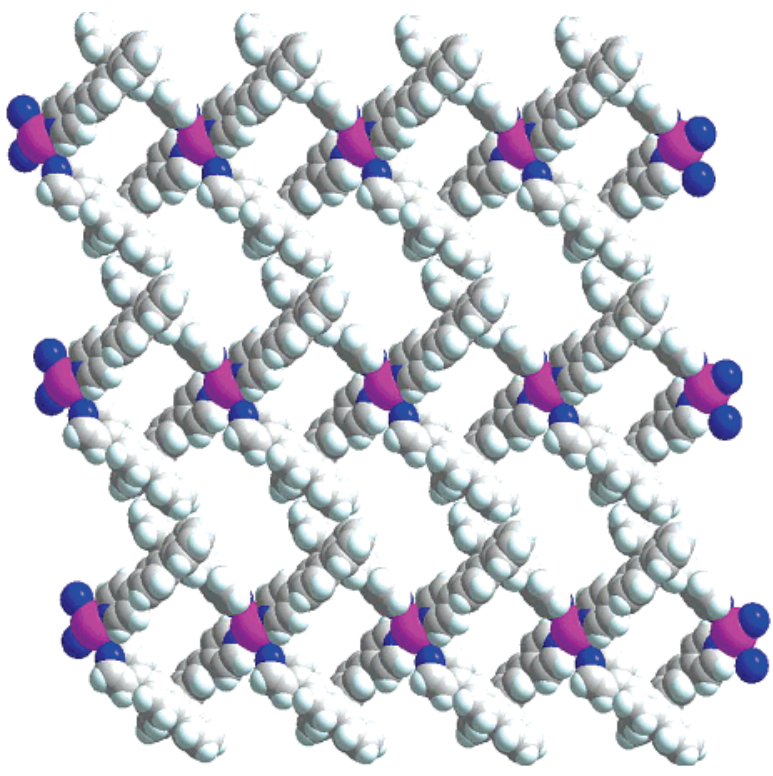

(a)

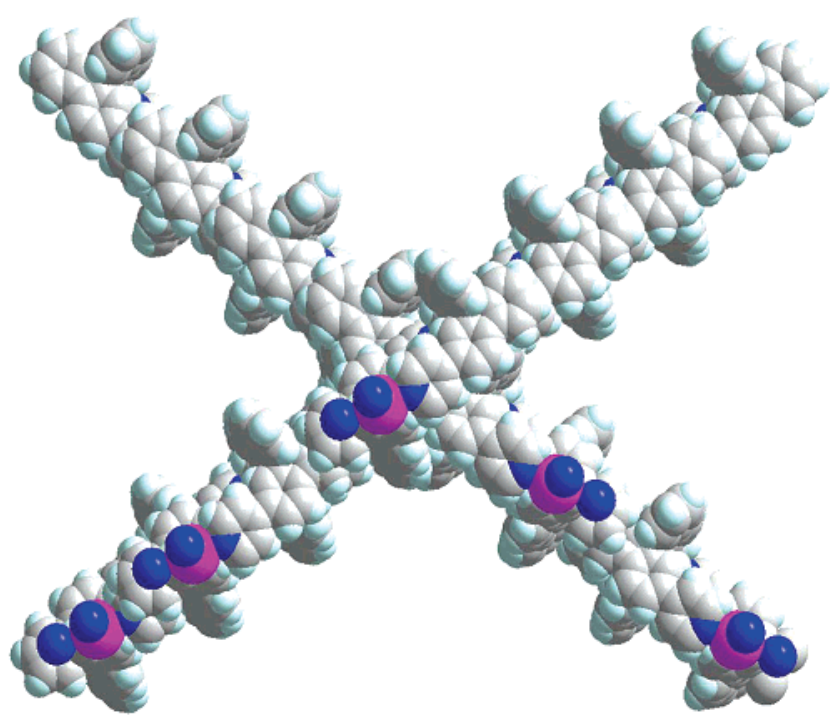

(b)

Figure 3. (a) Space-filling representation of the 2D layer framework formed by $\pi-\pi$ stacking of adjacent doublestranded polymer chains. (b) Overall $3 \mathrm{D}$ representation of the inclined and interpenetrated molecular networks of compound 6 viewed along the $b$-axis.

composed of two silver(I) ions and two $\mathbf{L}$ ligands has a distance between the two nonbonded corner silver atoms of ca. $14 \AA$; each square cavity has dimensions of ca. 8 $\AA \times 8 \AA$. It is interesting to note that adjacent doublestranded polymeric chains self-organize to form a $2 \mathrm{D}$ layer framework (Figure $3 \mathrm{a}$ ) through weak $\pi-\pi$ stacking interactions of phenyl rings in $\mathbf{L}$ with centroidcentroid separations of $3.958 \AA$. A rectangle cavity is formed with dimensions of ca. $14 \AA \times 8 \AA$. These $2 \mathrm{D}$ layers are mutually interpenetrated to give rise to a $3 \mathrm{D}$ interlock network depicted in Figure 3b. The vacant space of each square's and rectangle's cavities is fully occupied by the phenyl rings of $\mathbf{L}$ ligands, and consequently, these voids are effectively filled. 


\section{Conclusion}

In summary, we have established an unambiguous synthetic pathway to 2,2'-diiodo-9, $9^{\prime}$-spirobifluorene, which we applied in the synthesis of a novel right-angled ligand, 2,2'-bis(4-pyridyl)-9,9'-spirobifluorene (L). X-ray crystallographic analysis reveals that the pyridyl coordination sites of $\mathbf{L}$ are arranged nearly orthogonally (dihedral angle $=87.9^{\circ}$ ). This ligand self-assembles with silver(I) ions to form a polymeric two-stranded MOF, which has a slightly twisted square cavity as its basic building unit along the main axis of the chain, in a selfcomplementary organization process. By X-ray crystallographic analysis, we determined that the size of each cavity is $8 \AA \times 8 \AA$. We are intrigued to see whether the synthetic strategy that we have developed in this study is flexible enough to allow fine-tuning of the cavity sizes of the squares. Further structural modification of the right-angled ligand-e.g., by incorporating rigid, linear triple bonds between the spirobifluorene core and the pyridyl groups-would extend the length of the ligand and allow the square's cavity size to be increased. In addition, it should be possible to form new gridlike supramolecular architectures based on coordinated complexes formed from the right-angled ligands $\mathbf{L}$ and preformed trans-coordinated metal ions. Such studies are under investigation and will be reported in due course.

Acknowledgment. We are grateful for the financial support from the National Science Council of Taiwan.

Supporting Information Available: Crystallographic data of $\mathbf{L}$ and $\mathbf{6}$ (CIF). This material is available free of charge via the Internet at http://pubs.acs.org.

\section{References}

(1) Lehn, J.-M. Supramolecular Chemistry: Concepts and Perspectives; Wiley-VCH: Weinheim, 1995. (b) Comprehensive Supramolecular Chemistry; Atwood, J. L., Davies, J. E. D., MacNicol, D. D., Vögtle, F., Lehn, J.-M., Eds.; Pergamon: Oxford, 1996; Vol. 9. (c) Stang, P. J.; Olenyuk, B. Acc. Chem. Res. 1997, 30, 502. (d) Leininger, S.; Olenyuk, B.; Stang, P. J. Chem. Rev. 2000, 100, 853. (e) Fujita, M.;
Umemoto, K.; Yoshizawa, M.; Fujita, N.; Kusukawa, T.; Biradha, K. Chem. Commun. 2001, 509.

(2) Youinou, M.-T.; Rahmouni, N.; Fischer, J.; Osborn, J. A. Angew. Chem. Int. Ed. Engl. 1992, 31, 733. (b) Baxter, P. N. W.; Lehn, J.-M.; Fischer, J.; Youinou, M.-T. Angew. Chem., Int. Ed. Engl. 1994, 33, 2284. (c) Baxter, P. N. W.; Lehn, J.-M.; Kneisel, B. O.; Fenske, D. Angew. Chem., Int. Ed. Engl. 1997, 36, 1978.

(3) Stang, P. J.; Cao, D. H. J. Am. Chem. Soc. 1994, 116, 4981. (b) Stang, P. J.; Olenyuk, B. Acc. Chem. Res. 1997, 30, 502.

(4) Drain, C. M.; Lehn, J.-M. J. Chem. Soc., Chem. Commun. 1994, 2313. (b) Fan, J.; Whiteford, J. A.; Olenyuk, B.; Levin, M. D.; Stang, P. J.; Fleischer, E. B. J. Am. Chem. Soc. 1999, 121, 2741.

(5) Papaefstathiou, G.S.;Hamilton, T.D.; Friscic, T.; MacGillivray, L. R. Chem. Commun. 2004, 270.

(6) Weisburger, J. H.; Weisburger, E. K.; Ray, F. E. J. Am. Chem. Soc. 1950, 72, 4253.

(7) Weisburger, J. H.; Weisbuurger, E. K.; Ray, F. E. J. Am. Chem. Soc. 1950, 72, 4250.

(8) SMART V 4.043 Software for CCD Detector System; Siemens Analytical Instruments Division: Madison, WI, 1995.

(9) SAINT V 4.035 Software for CCD Detector System; Siemens Analytical Instruments Division: Madison, WI, 1995.

(10) Sheldrick, G. M. Program for the Refinement of Crystal Structures; University of Göttingen: Göttingen, Germany, 1993.

(11) SHELXTL 5.03 (PC Version), Program Liberary for Structure Solution and Molecular Graphics; Siemens Analytical Instruments Division: Madison, WI, 1995.

(12) Unfortunately, attempts to effect substitutive deamination of diamine 2 by treating it with tert-butylnitrite and copper(II) bromide in acetonitrile (Doyle, M. P.; Siegfried, B.; Dellaria, J. F., Jr. J. Org. Chem. 1977, 42, 2426) gave a mixture that was contaminated with overbrominated compounds, in contrast to a reported result (Wu, F.-I.; Dodda, R.; Reddy, D. S.; Shu, C.-F. J. Mater. Chem. 2002, 12, 2983); the desired 2,2'-dibromo-9, '9'-spirofluorene, however, could be isolated in low yield $(<30 \%)$ upon recrystallization from toluene.

(13) Zhu, Z.; Moore, J. S. J. Org. Chem. 2000, 65, 116.

(14) Initially, we attempted to follow a literature procedure (Pei, J.; Ni, J.; Zhou, X.-H.; Cao, X.-Y.; Lai, Y.-H. J. Org. Chem. 2002, 67, 4924) to brominate at these positions regioselectively, but in our hands, this approach furnished complicated mixtures of brominated compounds from which 2,2' dibromo-9, $9^{\prime}$-spirobifluorene, which we intended to use as a precursor for the preparation of $\mathbf{L}$, was isolated only in low yield after recrystallization several times from toluene.

CG049822O 